\title{
Hennie Human
}

\section{Karakterskepping in die rolprent Cry Freedom - 'n analise}

\begin{abstract}
This article looks critically at the aspect of charactarisation in the film Cry Freedom. A model is introduced for the analysis of characterisation in feature films. The model analyses the main characters in the film as symbols of the intended message. The aim is to determine the meaning of the message and to place the response to the film in perspective.

Particular attention is paid to the following aspects of the process of character creation: character formation, character revelation and character development.

The author comes to the conclusion that the main character in the film is the scriptwriter Donald Woods, and not the black activist, Steve Biko as has generally been accepted.
\end{abstract}

\section{Inleiding}

Die rolprent Cry Freedom het 'n polemiek in Suid-Afrika veroorsaak. Op 30 Julie 1988 berig Tim du Plessis in Beeld dat bomvoorvalle in verskeie dele van die land waar die rolprent vertoon sou word, voorgekom het. Hy haal die Minister van Inligting soos volg aan: "Cry Freedom stel die veiligheidsmagte in so 'n slegte lig dat hulle openbare beeld ernstig ondermyn word. Die prent se kru propaganda vind neerslag in die uitbeelding van radikale swartes as goed teenoor blankes - veral die regering en die polisie - wat as sleg en gevoelloos voorgestel word. Mnr. Steve Biko se verwerping van blankes en bevordering van geweld word onderbeklemtoon of glad nie uitgebeeld nie."

Op dieselfde dag haal Bruce Cameron 'n verteenwoordiger van die Kommissaris van Polisie in Saturday Star aan: "Cry Freedom contains propagandistic 
elements while various themes that are presented bear a marked similarity to the revolutionary onslaught conducted against the Republic."

Volgens Minette Nortje (1988:2) van Beeld was die Appèlraad oor Publikasies van mening dat die struktuur van die storie swak is en dat die gebruik van karikature, sensasionalisme en blatante bevooroordeling die rolprent gebrekkig laat voorkom.

Die reaksie op die rolprent laat die vraag ontstaan wat die vervaardigers se bedoeling met die rolprent was. In die Sunday Times van 11 Februarie 1990 som die draaiboekskrywer Donald Woods sy bedoeling soos volg op: "We who were involved with the making of it claimed it was an honest film depicting a true story."

Beeld berig op 20 Feburarie 1990 dat die rolprent in Suid-Afrika vrygestel gaan word (Anon,1990:3). Die noodmaatreëls van 1988 bestaan nie meer nie en Suid-Afrikaners sal self oor die "propagandistiese boodskap" in die rolprent kan besluit.

'n Rolprent is 'n komplekse samestelling van verskeie komponente. Een daarvan is die karakterskepping. 'n Ontleding van die karakterskepping in Cry Freedom kan moontlik op die outeursvisie (bronbedoelde betekenis) van die film ${ }^{1}$ dui. Dit kan ook daartoe bydra dat die owerhede se reaksie daarop in 1988 in perspektief gesien sal kan word. Vooraf egter eers 'n teoretiese besinning oor karakterskepping.

\section{Karakterskepping as kernvereiste vir die film}

Aan die hand van Field (1984:54) kan karakterskepping in draaiboeke soos volg opgesom word: "Karakterskepping is die hart en siel en senustelsel van 'n draaiboek. Die gehoor ervaar talle emosies as gevolg van die bestaan en optrede van die karakters en raak gevolglik by die stuk betrokke." Geller (1985:10) ken 'n sentrale plek aan die karakterskepping in 'n draaiboek toe: "As long as writers are interested in people, and are not browbeaten into assuming that a knowledge of screenplay form and camera angels and special effects is the sine qua non of writing; as long as character is all, there is yet a change of exciting the viewer, moving an audience, changing the way others have seen the world."

Willis (1967:18) is van mening dat die gehoor gunstig op 'n rolprent of televisiedrama sal reageer as hy omgee wat met die karakters in die betrokke stuk gebeur. Dit maak nie saak of die gehoor die karakters verag, haat of

1. Die geestelike inhoud van die boodskap (Van Schoor,1982:58). Omdat die film uiteindelik ook teks word, en die draaiboekstrywer die skepper van hierdie gerealiseerde teks is, word na die draaiboekskrywer as reële outeur verwys en na die bronbedoelde betekenis as outeursvisie. 
liefkry nie; solank die karakters die een of ander emosionele reaksie ontlok, is die karakterskepping suksesvol (Nash \& Oakey,1978:19).

'n Rolprent of televisiedrama is 'n samestelling van die hoogtepunte uit die betrokke karakters se lewe (Herman,1974:31). Die gehoor moet glo dat die karakters voor die begin van die verhaal gelewe het, en dat hulle na afloop daarvan met hulle lewens sal voortgaan. Daarom is die verhaal 'n tydsgebonde oomblik, 'n greep uit die karakters se lewe. Trouens, die verhaalintrige is maar net 'n voertuig waarin die karakters op reis gaan - 'n reis voor die gehoor verby (Root,1980:18).

Die wisselwerking tussen karakters en verhaalintrige word deur die karakterskepping gerig, want die draaiboekskrywer skryf oor mense en die dinge wat hulle doen (Vale,1986:100). So byvoorbeeld verklaar Marx (1989) dat die televisiereeks Agter elke man 'n voorbeeld is van 'n verhaalintrige wat uit die interpersoonlike verhoudings tussen die karakters ontwikkel het. Die verhaalintrige het uit die aanvanklike karaktersketse gegroei.

Volgens Root (1980:17) is die wisselwerking tussen karakterskepping en die verhaalintrige soos volg: die karakters moet die oorsaak en die intrige die gevolg in ' $n$ verhaal wees. Daar is net een verskil tussen 'n lewende en 'n dooie drama. In 'n dooie drama word die karakters deur die intrige beheer, in 'n lewende drama is die omgekeerde waar.

Teen hierdie agtergrond beskou Swain (1984:98) karakterskepping as die belangrikste bydrae wat 'n draaiboekskrywer tot 'n rolprent of televisiedrama kan maak. Die karakters is die lewensbloed van 'n dramatiese verhaal, en die konsep van lewensgetroue karakters is die grootste uitdaging waarvoor die draaiboekskrywer te staan kan kom (Root,1980:18).

Die verhaalintrige is egter nie onbelangrik nie. Bronfeld (1986:62) verklaar dat die wisselwerking tussen karakterskepping en die intrige ten beste deur die ontwikkeling van 'n sterk tema gehanteer word. Die draaiboekskrywer het 'n behoefte om met sy gehoor te kommunikeer en hy ontwikkel 'n tema waardeur betekenis oorgedra word - 'n betekenisraamwerk waarin die intrige geplaas word. Die tema moet 'n stewige konstruksie aan die draaiboek verleen en 'n verwysingsraamwerk voorsien waardeur die ontwikkehing van die karakters gerig word. (Bronfeld,1986:63). Die skep van 'n verhaal is dus nie 'n meganiese proses nie. Die karakt 'rs en die intrigt moet as integrerende eenheid ontwikkel word; die een nie ten koste van die ander nie (Paice, 1981:19).

\section{Die proses van karakterskepping - 'n analitiese model}

\section{1 ' $n$ Model is 'n raamwerk waarin daar na onderlinge verwantskappe gesoek kan word (Severin \& Tankard,1979:28)}

Daarom kan die samehang tussen die aspekte van karakterskepping met 
behulp van 'n model belig word. Karakterskepping word in die volgende model as 'n dinamiese, organiese groeiproses voorgestel.

3.2 Analitiese model van die proses van karakterskepping in 'n rolprent- of televisiedraaiboek

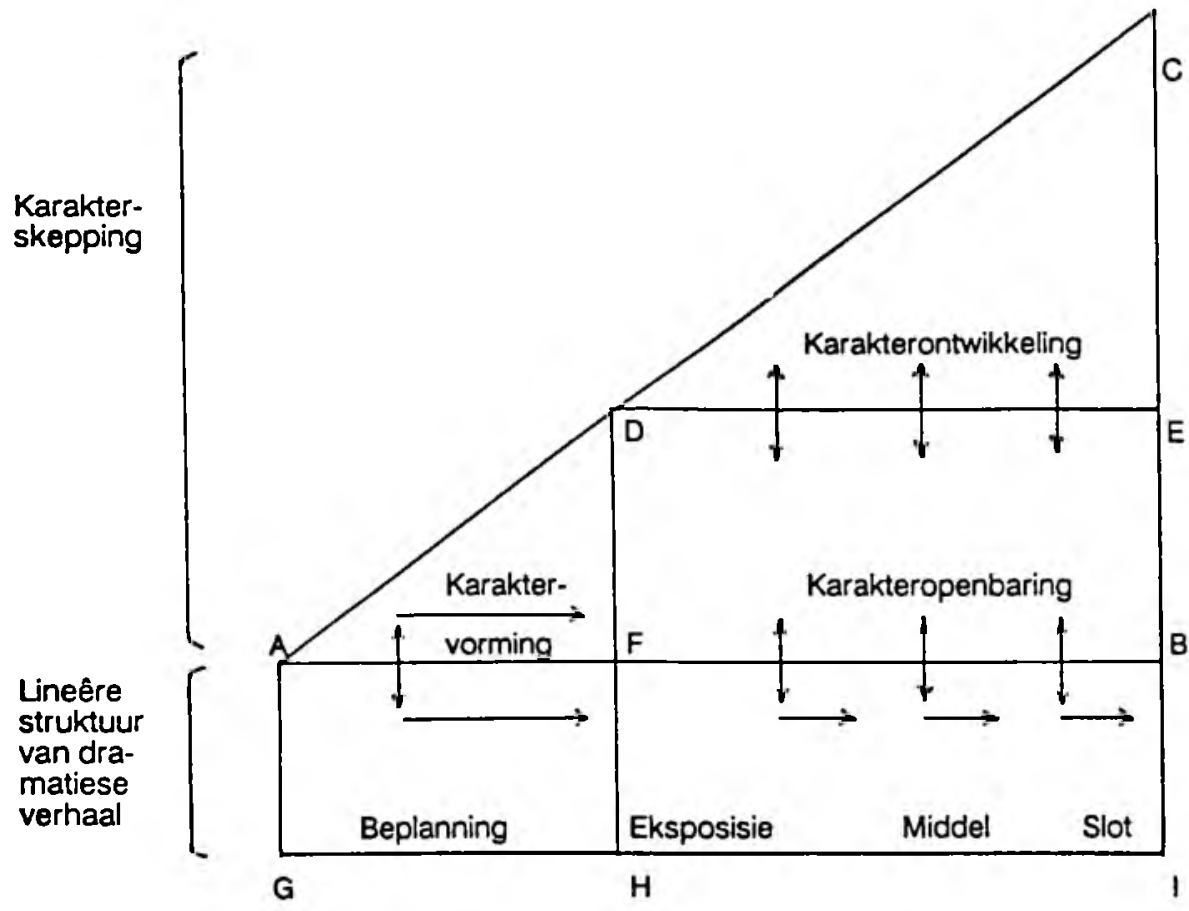

(Human,1988:292)

\subsection{Beskrywing van die model}

Die proses van karakterskepping word deur die lineêre struktuur van 'n dramatiese verhaal ondersteun. Sonder 'n verhaal kan daar geen sprake van karakterskepping wees nie. 'n Draaiboekskrywer sou wel indrukke van karakters in sy verbeeldingswêreld kon hê, en streng gesproke met die vorming van karakters besig kon wees, maar as hy die karakters nie binne die raamwerk van 'n verhaalbeplanning plaas nie, is hy nog nie met die proses van karakterskepping besig nie.

Die proses van karakterskepping word dus deur driehoek $\mathrm{ABC}$ voorgestel. Die ruimte tussen $A B G$ en I verteenwoordig die lineêre struktuur van 'n dramatiese verhaal. 
Die proses van karakterskepping bestaan uit drie komponente: karaktervorming, karakteropenbaring en karakterontwikkeling.

Karaktervorming word deur die driehoek AFD voorgestel. Die ruimte tussen DFB en E verteenwoordig karakteropenbaring, en die driehoek DEC beeld die aspek van karakterontwikkeling uit.

Die eerste interaktiewe wisselwerking waarvan kennis geneem moet word, is die wisselwerking tussen karaktervorming en verhaalbeplanning. Albei fases moet voltooi wees voordat die draaiboekskrywer met sy draaiboek kan begin, ongeag of hy 'n idee of 'n karakter as uitgangspunt gebruik.

Lyn DFH is die begin van die verhaal, die stuk wat aan die gehoor vertoon sal word. Die afstand tussen $\mathrm{H}$ en I stel die tydsduur van die stuk voor.

Die tweede belangrike wisselwerking in die model is die wisselwerking tussen karakteropenbaring en die drie fases waaruit die stuk bestaan: eksposisie, middel en slot. Karakteropenbaring is ' $n$ deurlopende proses. Dit begin in die eksposisie en eindig in die slot van die verhaal. Elke verskyning van die karakter moet verkieslik deur karakteropenbarende handeling en/of dialoog gekenmerk word.

Die derde wisselwerking in die model vind tussen karakteropenbaring en die verhaalintrige enersyds, en karakterontwikkeling andersyds, plaas. Karakteropenbaring hou gewoonlik met die ontwikkeling van die verhaalintrige verband. Die gehoor moet weet wat die uitwerking van die gebeure op die karakter is. Net so moet sy reaksie en optrede ook met die ontwikkeling van die verhaalintrige versoen word, sodat die karakter en die verhaalintrige saam ontwikkel kan word op pad na die hoogtepunt en ontknoping van die verhaal.

Lyn AC is die spannings- en ontwikkelingslyn. Dit neig opwaarts na die hoogtepunt (klimaks) van die verhaal. Dit begin reeds by karaktervorming en verhaalbeplanning, omdat die karakter en verhaal se potensiaal vir dramatiese ontwikkeling van die begin af aan beplan moet word. Die lyn simboliseer ook die organiese eenheid van die karakters en die verhaalintrige. Beide se spannings- en ontwikkelingslyn moet saam beplan, ontplooi en ontknoop word.

Die model toon aan dat die aspekte van karakterskepping nie fases van 'n ontwikkelingsproses is wat chronologies verloop nie. Daar is wel 'n chronologiese verband tussen karaktervorming enersyds, en karakteropenbaring en karakterontwikkeling andersyds. Karaktervorming moet verkieslik voltooi wees voor daar met die openbaring en ontwikkeling van die karakter (die skryf van die draaiboek) begin kan word.

Die aspekte van karakteropenbaring en karakterontwikkeling word aan 'n dinamiese wisselwerking geken. Dit verloop gelyktydig en is dimensies van 'n fiktiewe werklikheid wat voor die gehoor geleef word. As dit met die nodige kundigheid beplan word, sal die karakters in die draaiboek waarskynlik slaag, 
mits hulle deur die ander bydraers tot die kreatiewe proses as unieke, lewensgetroue en interessante mense vergestalt kan word.

\section{Die rolprent Cry Freedom - 'n toepassing van die model}

\subsection{Werklikheid en voorstelling}

Die rolprent Cry Freedom handel in hoofsaak oor die lewe van twee mense, die koerantredakteur Donald Woods en die swartbewussynleier Steve Biko. Dit kan as ' $n$ voorstelling van die empiriese werklikheid beskou word omdat die aanbiedingswyse 'n dokumentêre kleur daaraan verleen. So byvoorbeeld is belangrike datums en gegewens in titelvorm op die beeld aangebring en word daar deurgaans na die chronologiese verloop van bekende gebeure verwys.

In hierdie ondersoek sal daar nie gepoog word om die geskiedkundige gegewens te verifieer nie. Dit gaan oor die voorgestelde werklikheid en oor die aard en inhoud van die outeursvisie wat deur die karakters gesimboliseer en vergestalt word - die stoflike vorm wat die geestelike inhoud van die boodskap volgens Van Schoor (1982:58) moet aanneem om sintuiglik waarneembaar gemaak te kan word.

Die vraag is nie: is dit waar nie, maar: wat is die waarheid wat deur die reële outeur(s) oorgedra wil word? Die reële outeur(s) waarna verwys word, is die draaiboekskrywer, die regisseur en die vervaardiger van die rolprent. Dit is die persone wat gewoonlik oor die artistieke inhoud van 'n rolprent besluit.

Die reële outeur dra die betekenis van sy boodskap deur enkodering oor (Fauconnier,1981:44). Die doel is om die outeursvisie in die gemoed van die ontvangers (gehoor) op te wek (McCrosky,1986:4). Die karakters in 'n rolprent is simbole wat vir enkodering gebruik word. Hulle is, soos Fauconnier (1981:62) dit stel, voorstellings van begrippe. Hulle voldoen ook aan Bittner (1981:74) se beskrywing, en is samestellings van ander simbole. Daarom kan 'n ontleding van die karakterskepping in 'n rolprent, en van die interaktiewe wisselwerking tussen karakterskepping en die verhaalintrige, inhoud aan die outeursvisie gee.

Die karakterskepping in Cry Freedom sal vervolgens aan die vereistes van karaktervorming, -openbaring en -ontwikkeling getoets word, sodat die outeursvisie van die rolprent daarna beskryf kan word.

\subsection{Karaktervorming in die rolprent Cry Freedom}

\subsubsection{Ontwikkelingspotensiaal}

Karaktervorming is die eerste fase in die proses van karakterskepping, die fase waartydens mense geskep en vir hulle rol in die verhaal toegerus word (Root,1980:14). Volgens Field (1985:23) moet daar allereers na die karakter 
se "innerlike lewe" gekyk word. Dit is daardie deel van die karakter se lewe wat van sy geboorte af tot aan die begin van die verhaal verloop het - die proses waardeur die karakter gevorm is. Die doel is om die karakter so goed moontlik te leer ken sodat sy volle ontwikkelingspotensiaal in die loop van die verhaal ontgin sal kan word. Sy ontwikkelingspotensiaal kan aan die volgende dramatiese elemente gekoppel word (Brenner,1985:53).

\subsubsection{Dramatiese behoefte}

Die karakter se dramatiese behoefte hou verband met die vraag wat die karakter in die loop van die verhaal wil bereik of verkry (Field,1984:56). In Cry Freedom word die vraag taamlik volledig beantwoord. Beide karakters wil die Suid-Afrikaanse samelewing ingrypend verander.

Woods is aanvanklik deel van die stelsel, 'n "true white liberal" in Biko se woorde. Hy verwoord sy dramatiese behoefte deur sy gedrag soos volg te motiveer: "We liberals are trying to move toward integration." Dan word hy deur die stelsel verwerp. Hy word ingeperk en 'n nuwe behoefte ontstaan: die stelsel moet daadwerklik tot elke prys beveg word.

Biko se behoefte blyk uit sy verklarings aangaande die swartbewussynsbeweging. Tydens 'n besoek aan 'n swart kliniek verduidelik hy aan Woods waarom die kliniek gestig is. Dit moet dien as bewys van die swartman se menswaardigheid. Hy is nie, soos die witman hom probeer wysmaak, minderwaardig nie, ten spyte van die haglike omstandighede in die "black townships". Voor 'n geesdriftige sokkerskare verklaar hy: "We can all build a South Africa worth living in, a South Africa for equals, a South Africa as beautiful as this land is ... as beautiful as we are." Uit sy ontmoeting met Woods ontstaan 'n nuwe behoefte: "the education of a white liberal."

\subsubsection{Karakterisering}

Die karakter se dramatiese behoefte bring hom in beweging. Die vraag is: in watter rigting moet hy beweeg? (Swain,1984:105). Rilla (1974:19) is van mening dat ' $n$ karakter altyd in die rigting van sy doelwitte moet beweeg.

Woods se doelwitte ontstaan in die loop van die verhaal. Sy ontmoeting met Biko oortuig hom dat Biko nie 'n black racist is nie en dat die Suid-Afrikaanse regering met hom, as gematigde leier, moet onderhandel. Biko se dood lei tot 'n tweede doelwit: die korrupte, oneerlike, gevoellose Afrikaner-regering moet tot elke prys ontmasker en beveg word.

Biko se doelwitte spruit uit sy dramatiese behoefte voort. Hy wil sy mense ophef en uit die stelsel bevry. Dit is nie altyd duidelik hoe dit gedoen moet word nie. Hy moedig sy mense aan om hulle gesindheid te verander, maar hy wil ook (nie-gewelddadig?) 'n einde mak aan "... the naked terrorism of the government". In dié verband bly die vraag oor metodes in die lug hang. "We 
are at war", sê hy vir Woods, maar dis nie duidelik wat hy daarmee bedoel nie. In 'n toespraak verwys hy na die stryd teen die witman: "We'll stand up to him anyway he chooses, conflict if he likes ..." In 'n telefoongesprek met Woods na die dood van 'n swart gevangene is daar 'n bedekte dreigement in die volgende woorde: "One day justice will be done, and let's hope it won't be visited on the innocent." Biko druk sy idealisme soos volg uit: "We want blacks to stop accepting these hardships. They must develop hope." Ook hierdie doelwit is vaag en word nie deur die verhaalgegewe ondersteun nie.

\subsubsection{Gesigspunt}

'n Karakter tree vanuit sy gesigpunt op, hy reageer nie net blindelings op prikkels van buite nie (Field,1984:59). 'n Sterk gesigspunt skep konfliksituasies - 'n wesenskenmerk van die drama (Root,1980:32).

Woods en Biko het albei sterk gesigspunte, Dit hou met die verhaalintrige verband en voldoen gevolglik aan Swain (1984:102) se voorwaarde vir die motivering van konflik in 'n drama. Daarom is die konfliksituasies in die stuk geloofwaardig en is die grondslag vir die stryddinamiek in Cry Freedom van die begin af aan gelê.

\subsubsection{Houding en lewenswaardes}

'n Karakter se houding kan as 'n gebruiklike reaksie op 'n besondere situasie beskryf word (Pike \& Dunn,1984:104). Sy dominante houding is 'n gebruiklike reaksie op die lewe oor die algemeen en dit lei tot voorspelbaarheid en geloofwaardigheid. Mortensen (1972:101) beskryf 'n mens se houding as 'n ingesteldheid om konsekwent op boodskappe te reageer.

'n Houding gee gestalte aan die karakter se onderliggende lewenswaardes (Swain,1984:105). In die rolprent Money Truck 456 is daar goeie voorbeelde van dominante houdings:

- "I got no time for tomorrow. Today's all I can handle."

- "You do what's right, no matter what the rules say."

- "You gotta give the customers what they want."

'n Karakter se lewenswaardes bepaal die keuses wat hy in die loop van die verhaal gaan maak, veral in krisissituasies. Die basiese waardes wat die karakter motiveer, word deur sy doelwitte gereflekteer, maar sy volharding om die doel te bereik, openbaar die mate waarin sy lewe deur daardie waardes beïnvloed en beheers word (Willis,1967:62).

In Cry Freedom tree albei karakters konsekwent op. Hulle volhard in die strewe om die wêreld om hulle te verander, stel hulle aan gevare bloot, en is plooibaar en vindingryk in hulle stryd teen die stelsel. Woods oorleef omdat 
hy as witman teen die vergrype van die stelsel beskerm word. Biko sterf as slagoffer van die stelsel.

\subsubsection{Dominante karaktertrek}

Die dominante karaktertrek is die sentrale konsep van die karakter (Root,1980:20). Dit bepaal die karakter se plek en rol in die verhaal, en is 'n spieëlbeeld van die karakter se emosionele en intellektuele lewe (Herman,1974:30).

Woods se dominante karaktertrek is sy ondersoekende strewe na 'n regverdige samelewing. As skrywer/joernalis wil hy die waarheid dien, selfs al moet hy sy vaderland verlaat om dit te doen.

Biko word in die rolprent aan sy nederige billikheid geken. Hy word op 'n onwettige vergadering aan die skare voorgestel as 'n man wat "a little modest" is. Hy kan met objektiewe deernis na die wêreld kyk en dit aan Woods openbaar. Sy lydsame verset word deur sy dood tot martelaarskap verhef.

\subsubsection{Karakterskakering}

'n Karakter se karaktertrekke moet verkieslik vermeng word en daar moet na 'n gesonde balans gestreef word (Root,1980:22). Die eensydige voorstelling van karakters is oud-modies. Die gehoor weier meesal om met sulke karakters te identifiseer; die gehoor weet immers dat een-dimensionele mense nie in die werklikheid bestaan nie (Herman,1974:26). 'n Skurk kan nie net sleg wees nie, maar die goeie eienskappe in hom kan ook nie sonder meer verby 'n denkbeeldige middellyn beweeg nie. Dramatiese karakterwendings moet goed gemotiveer word sodat die karakter homself bly.

Die karakterskakering in Cry Freedom vertoon nie bogenoemde trekke nie. Beide Woods en Biko word betreklik ongenuanseerd voorgestel. Hulle karaktertrekke is oorwegend positief - simbole van wat goed en reg binne die konteks van die verhaalgegewe is. Die polisie, simbole van wat sleg is, word konsekwent eendimensioneel voorgestel. 'n Mens sou hulle as tipes kon beskou, wat volgens Conradie (1984:23) deur net een idee oorheers word: die stelsel moet in stand gehou word, brutaliteit, oneerlikhid en gevoelloosheid ten spyt. Hulle sou ook as bykarakters beskou kon word - karakters wat die struktuur van die verhaal en die waardes waarop dit gebou is, ondersteun deur die agtergrond te vorm waarteen die hoofkarakter sy stryd moet stry (Rilla,1974:80). Hierdie gebreke laat twee vrae ontstaan: wie is die hoofkarakter, en wie (of wat) is die antagonis? 'n Ontleding van die karakterontwikkeling verder aan (4.4.4) sal waarskynlik voldoende antwoord hierop gee. 


\subsubsection{Rasionalisering en identifisering}

Woods en Biko se optrede en gedrag word deur die reële outeur gerasionaliseer. Daar is 'n duidelike verband tussen optrede en gedrag, en agtergrond en ervaring. Daar word ook grootliks aan Willis (1967:61) se ideaal van identifisering voldoen - karakters van vlees en bloed vir wie die gehoor sal omgee deur met 'n groot mate van empatie die kollektiewe bewussyn met dié van die karakters te versoen. Die lewensvatbaarheid van die karakters sal nou in die volgende fase, karakteropenbaring, getoets word.

\subsection{Karakteropenbaring in die rolprent $\mathrm{Cry}$ Freedom}

Die karakter se optrede en gedrag word deur die proses van karaktervorming voorspelbaar gemaak (Brenner,1985:72). Die reële outeur weet hoe sy karakters gaan optree, maar hy weet nog nie hoe hy sy kennis van die karakters aan die gehoor moet oordra nie. Karakteropenbaring handel oor daardie deel van die karakter se lewe wat voor die gehoor geleef word abstrakte gedagtes wat vlees en bloed moet word (Pike \& Dunn,1985:20). Dit beteken dat die karakter aan die gehoor bekend gestel word deur wat hy doen (handeling) en wat hy sê (dialoog).

\subsubsection{Handeling}

Die reële outeur se idees en houding moet so ver moontlik deur die karakters se handelende optrede vergestalt word - uiterlike, fisiese optrede en die innerlike motivering daarvoor; wat die karakters waar doen en hoekom hulle dit doen (Hendriks \& Benoit,1963:19). Daar sal in die lig hiervan vervolgens slegs kortliks na die belangrikste komponente van die handeling in Cry Freedom gekyk word.

\subsubsection{Uiterlike lewe}

Volgens Field (1985:25) moet die karakter se uiterlike lewe in terme van professionele, persoonlike en private dimensies bedink word. Daar moet ook aandag gegee word aan die wisselwerking tussen die karakter se dramatiese persoonlikheid en sy omgewing (Vale,1986:106).

In Cry Freedom word Woods se uiterlike lewe omvattend openbaar. Die gehoor weet waar hy werk, hoe hy leef en dink. Sy verhouding met sy kollegas, sy gesin, sy vriende en die gemeenskap word dermate uitgebeeld dat die gehoor hom as volledige karakter leer ken. Daar word ook heelwat aandag aan dinamiese wisselwerking gegee: sy dramatiese behoeftes kan alleen deur stryd bevredig word; die konflikpotensiaal met ander karakters word op die spits gedryf toe hy twee lede van die SAP met 'n pistool konfronteer; die wisselwerking met die eie ek word deur sy twyfel, vrees en ontnugtering voorgestel. 
Biko is ' $n$ mistieke figuur. Dis nie altyd duidelik waar hy hom bevind en waarom nie. Sy omstandighede is 'n metafoor van sy status as ingeperkte. Is hy die leier van 'n weerstandsbeweging? Wie betaal hom en hoe slaag hy telkens daarin om, ten spyte van die veiligheidspolisie, te wees waar die verhaal hom wil hê? In Woods se geval word die veiligheidspolisie as 'n alomteenwoordige seekat voorgestel; Woods word selfs in sy slaapkamer beluister. Dit skep die indruk dat Woods die draer van die reële outeur se idees en houding is. Die reële outeur leef deur hom en pas 'n eie ervaringsveld op hom toe. Biko is die onbekende wat ontdek moet word, èn deur die reële outeur (wat deur die oë van Woods kyk) èn deur die gehoor.

\subsubsection{Toneelskikking}

Hulke (1976:62) beskou die toneelskikking as 'n raamwerk waarbinne die karakter visueel gedramatiseer kan word. Die toneelskikking bewerkstellig die manipulering van tyd en ruimte om uitdrukking aan die karakter se persoonlikheid en gemoedstemming te kan gee (Rilla,1974:99).

Die toneelskikking in Cry Freedom dra ruimskoots tot die openbaring van die karakters by. Woods is klaarblyklik 'n produk van die bevoorregte minderheid - Mercedes, swembad, toegang tot 'n minister, buitelandse reise, die beste regsverteenwoordiger en 'n huishulp. Hy lewe in die lig en doen dit met sekerheid en selfvertroue.

Biko is die antitese. Die gehoor hoor van hom, maar sien hom eers vyftien minute na die aanvang van die rolprent. Die sombere toon van die rolprent word om sy karakter gebou. Hy verteenwoordig die onderdrukte meerderheid. Vrees, armoede en 'n smeulende opstand is die kenmerke, en oorlewing die wagwoord van sy wêreld. Daarom ervaar die gehoor die "tegniese waardes" (Peters,1987:25) van die toneelskikking - die geloofwaardigheid van die voorstelling word deur die empiriese werklikheid in die rolprent ondersteun.

\subsubsection{Karakteropenbarende optrede}

'n Karakter word openbaar gemaak deur wat hy doen en hoe hy dit doen (Field,1984:79). Die rolprent Thief is 'n voorbeeld. In die eerste tien minute van die rolprent is daar geen dialoog nie. Die gehoor sien 'n inbraak en leer die hoofkarakter deur sy optrede ken - 'n bobaasinbreker wat vindingryke tegniese hulpmiddels gebruik en presies weet waarna hy soek. Hy openbaar sy kundigheid deur net die beste stene uit 'n groot diamantversameling te haal.

In Cry Freedom is daar min aandag aan karakteropenbarende optrede gegee, èn wat voortdurend èn wat spesifieke handeling betref. Die reële outeur se boodskap word hoofsaaklik deur dialoog en die mise-en-scéne oorgedra. Die karakters word elemente van 'n organiese, dialektiese proses wat hulle 
meevoer na 'n eindbestemming. Hulle word uitgelewer aan die eise van die verhaalintrige en dit lyk of die outeur hulle willekeurig manipuleer.

\subsubsection{Metode van bekendstelling}

Karakteropenbaring is die akkumulasie van besonderhede waardeur die karakter deur 'n stelselmatige en ordelike proses gedefinieer word (Rilla,1984:75).

In Cry Freedom word van beide progressiewe en indirekte metodes van bekendstelling gebruik gemaak. In Woods se geval sien die gehoor hoe hy deur die gebeure in die verhaal van pasifisme tot totale betrokkenheid gevorm word. Biko se vrou nooi hom na Biko se begrafnis toe, want "you are one with your brothers and sisters now". Hy wil die land verlaat, want "we know what this country is like now". Biko word hoofsaaklik deur die oë van ander karakters gesien. Hy is as 't ware 'n historiese figuur wat in sy eie tyd in historiese perspektief geplaas word. Hy word deur die reële outeur gebruik om 'n bepaalde perspektief te regverdig.

\subsubsection{Die konsekwente uitbeelding van karakter}

In Cry Freedom omseil die reële outeur die voorwaarde van konsekwentheid deur die eensydige voorstelling van die karakters. Die karakters is eerbaar en voldoen aan die hoogste beskawingsnorme wat binne die verhaalkonteks gestel word. Biko se verdraagsaamheid grens selfs aan naïewe goedgelowigheid. Woods bel hom met die nuus van 'n skolestaking in Soweto. Biko reageer soos volg: "They're kids. They may shout a little bit, break a few windows, but ..." Dan sien die kyker hoe die kinders genadeloos neergeskiet word. Ook blankes in siviele klere maak jag op hulle. Woods en Biko se strewe na billikheid word dus nie objektief getoets nie. Trouens, die stelsel is so boos dat hulle billikheid selfs onvanpas is. Die stelsel moet vernietig word, daar is geen middeweg nie. En die gehoor kan nie anders as om saam te stem nie.

\subsubsection{Kontrastering}

Kontrastering is 'n tegniek wat gebruik word om konfliksituasies te bou (Egri,1985:119). Die kontrastering van karakters lei tot die beweging van polêre uiterstes na sentrale konflikpunte toe (Nash \& Oakey,1978:7).

Die karakters in Cry Freedom is so skerp gekontrasteer dat daar sprake is van Egri (1985:114) se konsep van orkestrering. Dit lyk of die strydende partye nommerpas ontwerp is vir die stryd. Hulle staan kompromieloos teenoor mekaar, elk gereed om tot die dood toe te stry. Die onafwendbaarheid van 'n Armageddon in Suid-Afrika word telkens deur beide Woods en Biko beklemtoon. Woods is aanvanklik geskok oor 'n stelling deur een van Biko se 
vriende: "We want to wipe the whole table clean ... it's an African table" (Suid-Afrika). 'n Lid van die veiligheidspolisie, ene kaptein De Wet, gluur Biko vasberade aan: "We'll never give up," beloof hy. Toe Woods ingeperk word, fluister hy: "Kruger's gone crazy," en aan die veiligheidspolisie verklaar hy: "The days of a few whites running a black country are over."

\subsubsection{Dialoog}

Ofskoon dialoog een van die belangrikste karakteropenbarende instrumente in 'n draaiboek is, sal die dialoog in Cry Freedom nie hier volledig ontleed word nie. Die terrein is gewoon te wyd en daar sal gevolglik met 'n paar oorsigtelike opmerkings volstaan word.

Die dialoog in Cry Freedom dra tot die orkestrering van die stuk se konflikpotensiaal by. Dit dien as uitstalvenster van die reële outeur se vertolking van die verhaalgegewe en is dus doelgesentreerd. Daar word selde of ooit van die sentrale tema afgewyk en die inligtingsfunksie word gevolglik oorbeklemtoon. Die gehoor moet blykbaar oortuig word dat hy die empiriese werklikheid herleef en dat hy nie ter wille van die stuk se vermaaklikheidspotensiaal op syspore gelei sal word nie.

Die gevoelsfunksie van dialoog word in Cry Freedom ter ondersteuning van die inligtingsfunksie aangewend. Die gehoor se reaksie op die gebeure word deur die karakters verwoord sodat 'n uniforme boodskap oorgedra kan word. Dit lei daartoe dat die dialoog soms meganies en voorspelbaar word, die karakters doen soms weinig meer as om net op die reële outeur se "wenke" te reageer.

Die deeglike vorming van die karakters in Cry Freedom het tot gevolg dat die dialoog oorwegend karakteriserend van aard is. Die reële outeur ken sy karakters en gebruik die dialoog om hulle getrou aan hul aard te hou. Dit is egter nie 'n uitgemaakte saak of hy sy kennis van die karakters doeltreffend oordra nie. Die gehoor ken net daardie aspekte van die karakters wat direk uit die sentrale tema voortvloei.

\subsection{Karakterontwikkeling in die rolprent $\mathrm{Cry}$ Freedom}

Karakterontwikkeling hou verband met die ontwikkelingsprosesse in 'n dramatiese verhaal (Human,1988:194). Dit vind binne 'n interaktiewe ontwikkelingsraamwerk plaas en is saam met die verhaalintrige deel van 'n organiese geheel wat na 'n dramatiese hoogtepunt gevoer word - die ontknoping van beide fisiese en emosionele komponente. Die ontwikkelingsprosesse word vervolgens op Cry Freedom van toepassing gemaak.

\subsubsection{Karakterverandering}

In die literatuur is daar meningsverskil oor die vraag of karakterverandering 
'n wesenskenmerk van 'n dramatiese verhaal is (vgl. Egri,1985:60 en Willis, 1967:74).

Elemente van beide benaderings kom in Cry Freedom voor. Die ontwikkeling van Woods se karakter is soortgelyk aan die karakterverandering in die rolprent Professor Mamlock. Hierdie rolprent handel oor die optrede van 'n professor in Duitsland tydens Hitler se bewind. Die professor is aanvanklik onbetrokke, hy steur hom min aan die nuwe bewind, maar dan reik die politiek tot in die klaskamer. Van sy kollegas word gemartel en hy raak bekommerd. Hy is egter nog nie bereid om daadwerklik op te tree nie en weier om op versoek van sy vriende te ontvlug. Die toestand versleg en hy word bang. Hy wil vlug maar hy weet nie hoe of waarheen nie. Sy angs maak hom desperaat en hy kies kant en sluit hom by die weerstandbeweging aan. Aan die einde van die rolprent is professor Mamlock totaal betrokke, hy sterf vir die saak waaraan hy glo. Sy karakterontwikkeling (en verandering) lê in die proses waardeur hy tot optrede beweeg is.

Woods is aanvanklik 'n wetsgehoorsame, maar opstandige koerantredakteur. Hy bly binne die grense van die wet en is in 'n sin onbetrokke. Sy ontmoeting met Biko is die katalisator wat die ontwikkelings- en veranderingsproses op dreef kry. Hy word aan die omstandighede en gedagtes van die swart gemeenskap blootgestel en raak betrokke. Uiteindelik moet hy na die buiteland vlug om sy stryd teen die Suid-Afrikaanse regering te kan voortsit.

Daar is min sprake van karakterverandering in Biko se geval. Hy is aan die begin van die verhaal reeds so volledig gevorm en ontwikkel dat karakterverandering sy geloofwaardigheid sou kon benadeel. 'n Kompromie met sy omstandighede is onmoontlik. Hy kan ook nie, soos Woods, na ekstreme uiterstes uitwyk nie. Die gehoor moet juis glo dat hy 'n nederige, billike idealis is wat met die rede wil veg maar hom teen redelose vooroordeel te pletter loop. Biko is ' $n$ heldefiguur. Hy is verhewe bo die blinde haat en woede om hom. Hy betrag die wêreld met 'n glimlag en ontsenu sy vyande (ook 'n regter) met sy vlymskerp insigte. Sy koersvaste wil kan op net een manier gebreek word: hy moet sterf.

\subsubsection{Die proses van besluitneming}

Vale (1986:124) onderskei drie komponente van die proses: die besluitnemingsmotief, die voorneme en die doel.

In Cry Freedom is Woods die besluitnemer. Sy motiewe ontstaan uit die kragte van affiniteit en afkeer. Hy wil hom met die ideale van die swart bewussynsbeweging assosieer en hy wil hom van die wit establishment losmaak. So groei sy voorneme om aktief betrokke te raak en die doel te bereik - 'n Suid-Afrika waarin die meerderheid regeer en alle skeidsmure tussen groepe afgebreek is. Sy besluit om op te tree spruit voort uit Biko se voorneme om 'n groep studente in Kaapstad te gaan toespreek. Hy word 
gearresteer en sterf in die gevangenis. Dit is die motief vir Woods se finale voorneme om Biko se verhaal aan die wêreld te vertel.

\subsubsection{Karakterontwikkeling en verhaalintrige}

Die verhaalintrige vorm die grondslag waarop die karakter se ontwikkeling gebou word (Swain,1984:117). Volgens Vale (1986:157) word die interaktiewe wisselwerking tussen karakterontwikkeling en die verhaalintrige gekenmerk deur faktore soos oorsaak en gevolg, versteuring en aanpassing. Die versteuring van die mens se rus en vrede lei tot die motief en voorneme om die versteuring te verwyder en na die normale lewensloop terug te keer - om dus 'n aanpassing te maak. Tussen die pole van versteuring en aanpassing moet die karakter volledig ontwikkel word.

In Cry Freedom word Woods en Biko se karakterontwikkeling deur verskeie versteurings bevorder: die sloping van die plakkerskamp by Crossroads, Biko se arrestasie na 'n toespraak by 'n onwettige byeenkoms, die besoek van die veiligheidspolisie aan Woods na sy gesprek met minister Kruger, en die daaropvolgende hofsaak omdat hy die naam van ' $n$ informant weerhou, die "selfmoord" van 'n gevangene, die aanval van die "veiligheidspolisie" op Biko se swart kliniek en op Woods se huis, Biko se dood en Woods se aandrang om sy verminkte liggaam te sien, naamlose dreigemente teen Woods se familie, T-hempies wat met jeukpoeier besmet is en aan Woods se kinders gegee is, Woods se inperking, ensomeer.

Hierdie kernmomente dwing Woods om handelend op te tree. Hy vlug na Brittanje om sy boek oor Biko te publiseer - in Suid-Afrika is daar immers geen vryheid meer nie. Biko verdra die versteurings. Tot aan die einde van sy lewe is hy die draer en simbool van 'n Messiaanse boodskap.

\subsubsection{Doelwitbereiking}

In 'n dramatiese verhaal kan 'n karakter sy doelwit gewoonlik net deur stryd bereik (Bronfeld,1986:58). 'n Verhaal begin eers as die hoofkarakter hom verbind om sy doel te bereik. Dan word die onderliggende "storievraag" gevestig.

In Cry Freedom tree die proses van doelwitbereiking eers na Biko se dood in werking. Die storievraag is: sal Woods daarin slaag om na veiligheid te vlug? Sal sy familie wat in lewensgevaar is uit die kloue van die veiligheidspolisie kan bly? Sy vrou wil aanvanklik niks van die vlugplan weet nie - "You'll get killed just trying to escape, or thrown into prison!" Woods moet kies, want dit gaan oor 'n keuse wat die karakter moet maak (Swain,1984:120). Hy moet besluit of hy die stelsel van binne of van buite gaan beveg. Sy keuse word deur die gevaarlike toestand waarin hy en sy gesin hulle bevind, geregverdig. Die reële outeur bevestig sy keuse deur struikelblokke op sy weg te lê: 'n vol rivier keer hom voor, die SA-Lugmag wil sy vliegtuig afskiet, die veiligheidspolisie 
(en hulle honde) staan gereed, 'n vragmotor vol soldate ry verby, ensomeer.

\subsubsection{Doelgesentreerde karakterontwikkeling}

Die drie kenmerke van die doelgesentreerde karakterontwikkeling is voorspelbaarheid, beklemtoning van die negatiewe, en die korrekte plasing van krisissituasies (Herman,1974:39).

Hierdie kenmerke is hoofsaaklik op Woods se karakterontwikkeling van toepassing. Aangesien Biko se doel nie deur pertinente doelwitte onderskraag word nie, is daar min onsekerheid oor die vraag of hy die doel sal bereik of nie. Sy dood is 'n tematiese wending en nie die gevolg van doelgesentreerde karakterontwikkeling nie.

Woods se ontvlugting skep spanning. Die beginsel van toenemende intensiteit is hier ter sprake. Dit is vir die gehoor belangrik om te weet of hy gaan slaag, want hy is binne die verhaalkonteks innemend en aanvaarbaar. Sy keuse is eerbaar en spruit voort uit 'n intense ervaring - Biko se dood. Die gehoor is gereed om die epiese vlug mee te maak sodat die doel bereik en die kwaad vergoed kan word.

\subsubsection{Stryddinamiek}

Die stryddinamiek van 'n dramatiese verhaal word deur twee fases gekenmerk, 'n konflik in die karakter self vanweë die omstandighede waarin hy hom bevind, en die konfrontasie met iets of iemand wat daaruit voortspruit (Egri,1985:60). Hierdie proses sal nie hier volledig bespreek word nie. Daar sal nou slegs na die profiele van die konfrontasiekomponente gekyk word.

Die hoofkarakter in ' $n$ dramatiese verhaal is die protagonis (Goodman,1982:22). Die protagonis is die karakter met die belangrikste doelwit en die sterkste dryfkrag, hy neem die belangrikste besluite (Field,1985:22). Die rolprent Butch Cassidy and the Sundance Kid is 'n voorbeeld. Albei karakters is belangrik, maar Butch is die hoofkarakter. Dit is hy wat lei, Sundance volg. Die hoofkarakter bring die verhaal in beweging, hy doen wat hy doen omdat hy is wat hy is (Egri,1985:107).

Wie is die protagonis (hoofkarakter) in Cry Freedom? Bogenoemde uitsprake dui op net een man: Donald Woods. Die hele verhaal word uit sy oogpunt gesien, of soos Brenner (1985:81) dit stel, hy is die middelpunt van die verhaal. Die verhaal begin met die sloping van Crossroads en Woods se reaksie daarop. Dit eindig met Woods se peinsende terugblik op die gebeure tydens sy vlug na vryheid. Biko is die katalisator waardeur Woods se lewe verander word. By Biko se begrafnis sing hy aanvanklik Nkosi Sikele i'Afrika huiwerig saam. Dan verduidelik hy aan sy kinders wat die woorde beteken. Die klem val op die woord "us"; hy is een van sin en strewe met die omstanders as hy uit volle bors voortsing. Die oorheersende indruk is egter 
dat Cry Freedom die motivering vir Woods se boek ook Biko moet wees, en dat die gehoor oortuig moet word dat die boek (en die rolprent) noodsaaklik was om die doel te bereik: die wêreldwye ontmaskering van die SuidAfrikaanse politieke stelsel.

Die antagonis daarteenoor, is die protagonis se belangrikste opponent (Root,1980:42). Hy moet feitlik net so sterk en meedoënloos as die protagonis wees (Egri,1985:118). 'n Geveg is immers net interessant as die deelnemers 'n gelyke kans het om te wen. Die antagonis hoef nie 'n persoon te wees nie (Goodman,1982:6). Swain (1984:32) beskou alle faktore wat in die protagonis se pad na sy doelwit staan as elemente van die begrip antagonis alles wat vir hom gevaar inhou, sy lewe, geluk of waardigheid bedreig. Conradie (1984:24) som die begrip soos volg op: "Dit is die teenstander wat die worsteling en die krisis by die protagonis veroorsaak - die agtervolger, bedreiger, kweller."

In Cry Freedom word die antagonis by sy naam genoem: die Afrikanerregering. Woods reageer skerp op Biko se beskrywing van die swartman se bestaanstryd: "You're talking about the Afrikaner government. Don't blame all the whites for apartheid." Toe Woods twee swart verslaggewers by sy koerant aanstel, slaan sy nuusredakteur se vooroordeel spottend deur. "Ja baas", antwoord hy op Woods se bevele. Biko verduidelik dat die swartbewussynsbeweging ontstaan het toe die swartman besef het "what the Afrikaners were doing to us". Hy word twee keer deur lede van die SAP gekonfronteer. Hulle verneder hom met die skeldwoord "kaffir". Hulle aksent verraai hulle moedertaal, Afrikaans. Die korrupte polisie-offisier dra 'n Afrikaanse van, De Wet noem hulle hom. Toe die "veiligheidspolisie" 'n onwettige strooptog op 'n swart kliniek uitvoer, word daar in die donker Afrikaans gepraat: "Nou sal ons sien, ... dit sal die donners wys". Minister Kruger spreek Woods oor sy Afrikaner-herkoms toe en vra: "You think we're gong to give that all up?" Woods wys hom daarop dat die swartman se verset verstaanbaar is “. . . after you've (die Afrikaners) taken all the land away ..." Die minister verwoord die gehoor se vermoede aangaande sy mense: "We're not really the monsters we're made out to be", sê hy, maar kort daarna word Woods se huishulp deur 'n polisieman met die naam, Kobus, lastig geval. Die gevoellose bewaarders in die gevangenis praat met 'n Afrikaanse aksent terwyl 'n gevange 'n pynkreet op die klankbaan laat hoor. Die sterwende Biko word ewe gevoelloos in 'n bokspringende ambulans 700 myl ver na 'n polisiehospitaal vervoer. 'n Swart patriarg vervoer Woods die laaste paar kilometer na vryheid toe. Sy jubelkreet word 'n refrein wat sy rammelkasmotor oor die rante begelei: "The Boers will sh. . themselves! Kruger will sh. . . himself! Vorster will sh. . . himself! Botha will sh. . . himself!" Aan die einde van die rolprent is daar 'n terugflits ter verklaring van die Sowetoopstande van 1976. Die identiteit van die antagonis word vir oulaas omskryf. Woods is aan die woord: "The school children are on strike ... They refuse to study Afrikaans ... refuse to be trained simply as servants of the system 


\section{Gevolgtrekking}

Aan die begin van hierdie artikel is daar twee vrae gevra:

- wat was die vervaardigers se bedoeling met die rolprent?

- wat is die boodskap wat daarin vervat is?

In 4.1 is daarop gewys dat die outeursvisie deur die karakters gesimboliseer en vergestalt word, en dat 'n ontleding van die karakterskepping in Cry Freedom moontlik antwoorde op bogenoemde vrae sal kan verskaf.

Die resultaat van die ontleding kan soos volg opgesom word:

\subsection{Karaktervorming}

Die karakters is redelik volledig gevorm. Die outeur ken 'n bepaalde plek en rol in die verhaal aan hulle toe en sorg dat hulle daarvoor toegerus is. Woods se karakter is meer volledig gevorm as Biko s'n. Hy beweeg in die rigting van duidelike doelwitte. En omdat hy meer genuanseerd gevorm is, kry hy die geleentheid om meer aspekte van sy persoonlikheid te openbaar.

\subsection{Karakteropenbaring}

Woods se karakter word meer volledig geopenbaar as Biko s'n, waarskynlik omdat hy meer volledig gevorm is. Die reële outeur leef deur Woods en nie deur Biko nie. Biko is as't ware deel van die toneelskikking waarbinne Woods se stryd visueel gedramatiseer kan word. Hy is die vleeslike gestalte van ' $n$ idee, die tema waarna in 2 verwys is. Biko is die idee. Na sy dood word Woods die draer van die idee: 'n man met 'n missie. Daarom kry die stuk se tema gestalte in die karakteropenbaring: Biko is dood maar die swartbewussynsidee leef voort.

\subsection{Karakterontwikkeling}

Daar is min sprake van karakterontwikkeling in Biko se geval. Die reële outeur ervaar Biko se menswees van buite af en kyk saam met hom uit onbetrokke hoogtes op die gebroke mensdom neer. Biko is nie deel van die ontwikkelingsprosesse in die verhaal nie. $\mathrm{Hy}$ is die ontwikkelingsproses wat Woods se karakterontwikkeling rig en bevorder. Daarom is Woods die hoofkarakter, die protagonis is die stuk, en handel Cry Freedom in hoofsaak oor sy stryd.

\subsection{Outeursvisie}

Die outeursvisie in Cry Freedom kan soos volg saamgevat word: Donald Woods voer, namens die Swartbewussynsbeweging, 'n stryd teen die Afrikanerregering in Suid-Afrika. Die dood van Steve Biko regverdig sy stryd en 
verklaar waarom dit nodig was om 'n rolprent te maak - Woods is nou die draer van 'n idee wat, anders as Biko, nie mag sterf nie.

As hierdie samevatting korrek is, kan die rolprent as 'n geslaagde weergawe van die outeursvisie beskou word. As die reële outeur 'n ander betekenis wou oordra, moes die karakterskepping anders daar uitgesien het, en sou die sukses van die rolprent in ander faktore gesoek moes word.

\section{Bibliografie}

Anon. 1990. Cry Freedom word landwyd uitgereik. Beeld, Feb. 20/:3.

Brady, J. 1982. The craft of the screenwriter. New York: Simon and Schuster.

Brandt, G.W. 1981. British television drama. Cambridge: Cambridge University Press.

Brenner, A. 1985. The TV-scriptwriter's handbook. Cincinnati: Writer's Digest Books.

Bronfeld, S. 1986. Writing for film and television. New York: Simon and Schuster.

Cameron, B. 1988. Cry Freedom. Saturday Star, July 30/:1.

Conradie, P.J. 1984. Hoe om 'n drama te ontleed. Pretoria: Academica. (Reuse-Blokboeke, RB9.)

Du Plessis, T. 1988. Cry Freedom. Beeld, Julie 30/:1.

Egri, L. 1985. The art of dramatic writing. New York: Simon and Schuster.

Field, S. 1984. The screenwriter's workbook. New York: Dell.

Field, S. 1985. The foundations of screenwriting. New York: Dell.

Geller, S. 1985. Screenwriting. New York: Bantam.

Goodman, E. 1982. Writing television and motion picture scripts that sell. Hollywood: Westbourne.

Hendrik, A. \& Benoit, A. 1963. Schrijven voor de televisie. Antwerpen: NV Standaard.

Herman, L. 1974. Screen playwriting for theater and television films. Ontario: New American Library.

Hulke, M. 1976. Writing for television in the 70's. London: Adam and Charles Black.

Human, H.J. 1988. Karakterskepping in rolprent- en televisiedraaiboeke. Potchefstroom. (Ongepubliseerde M.A.-verhandeling, PU vir CHO.)

Marx, F. 1987. Mondelinge mededeling aan outeur. Johannesburg. (Kassetopname in besit van outeur.)

Mortensen, C.D. 1972. Communication: the study of human interaction. New York: McGrawHill.

Hash, C. \& Oakey, V. 1978. The Screenwriters's handbook. Toronto: Fitzhenry \& Whiteside.

Nortje, C.J. 1988. Mondelinge mededeling aan outeur. Johannesburg. (Kassetopname in besit van outeur.)

Nortje, M. 1988. Cry Freedom. Beeld, Julie 30/:2.

Paice, E. 1981. The way to write for television. London: Elm Tree.

Peters, J.M. 1987. Model for the aesthetic analysis of a film. Communication 13 (2):24-27, Nov.

Pike, F. \& Dunn, T.G. 1985. The playwright's handbook. New York: Nal Books.

Rilla, W. 1974. The writer and the screen. New York: Morrow Quill.

Root, W. 1980. Writing the script. New York: Holt, Rinehart and Winston.

Severin, W.J. \& Tankard, J.W. 1979. Communication theories: origins, methods, uses. New York: Hastings.

Swain, D.V. 1984. Film scriptwriting. London: Focal.

Vale, E. 1986. The technique of screen and television writing. New York: Simon \& Schuster.

Van Schoor, M. 1982. Bestaankommunikasie. Bloemfontein: P.J. de Villiers.

Willis, E.E. 1967. Writing television and radio prgrams. Chicago: Holt, Rinehart and Winston.

Woods, D. 1990. Let's have real radio, real TV. Sunday Times, Febr. 11/:21.

\section{Potchefstroomse Universiteit vir CHO}

